2. To: (Receiving Organization)

Distribution

5. Proj./Prog./Dept./Div.:

Waste Management Services

8. Originator Remarks:

Release document

11. Recelver Remarirks:

11A. Design Baseline Document? $\square$ Yes $\square$ No
4. Related EOT No:

NA

7. Purchase Order No

9. Equlp./Component No.:

NA

10. System/B/dg./Facility:

Hanford Site

12. Major Assm. Dwg. No.:

NA

13. Permit/Permit Application No.:

NA

14. Required Response Date:

NA

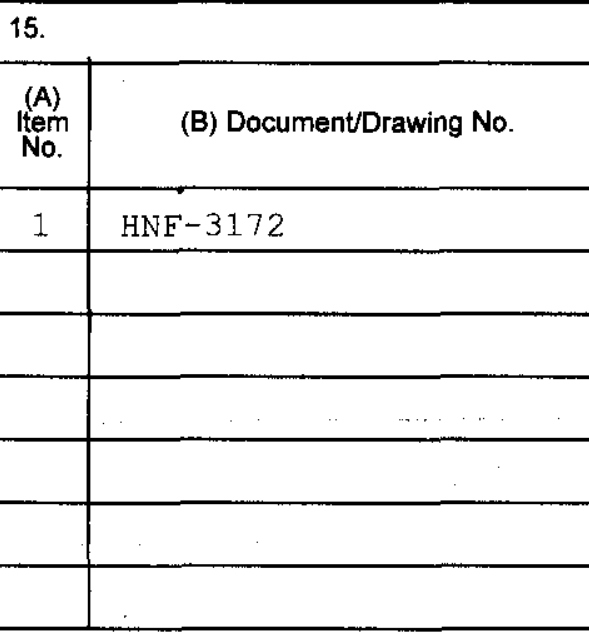

DATA TRANSMITTED

\begin{tabular}{|c|c|l|}
\hline $\begin{array}{c}\text { (C) Sheet } \\
\text { No. }\end{array}$ & $\begin{array}{c}\text { (D) Rev. } \\
\text { No. }\end{array}$ & (E) Title or Description of Data Transmitted \\
\hline NA & 0 & Hanford Site Liquid Waste \\
\hline & & Acceptance Criteria \\
\hline
\end{tabular}

16.

\begin{tabular}{|l|l|}
\hline & \\
\hline & \\
\hline & \\
\hline & \\
\hline
\end{tabular}

Approval Designator (F)

E, S, Q, D OR N/A (See WHC-CM-3-5, Sec. 12.7)

1. Approval
2. Release
3. Information

Reason for Transmittal (G)

4. Review

5. Post-Review

6. Dist. (Receipt Acknow. Required)

KEY
(G)

\begin{tabular}{|c|c|c|c|}
\hline (F) & $(\mathrm{G})$ & $(\mathrm{H})$ & $(\mathrm{I})$ \\
\hline $\begin{array}{c}\text { Desproval } \\
\text { nator }\end{array}$ & $\begin{array}{c}\text { Reason } \\
\text { frans-- } \\
\text { mittal }\end{array}$ & $\begin{array}{c}\text { Origi- } \\
\text { nator } \\
\text { Dispo- } \\
\text { stion }\end{array}$ & $\begin{array}{c}\text { Receiv- } \\
\text { er } \\
\text { Dispo- } \\
\text { sition }\end{array}$ \\
\hline$F$ & & &
\end{tabular}

17.

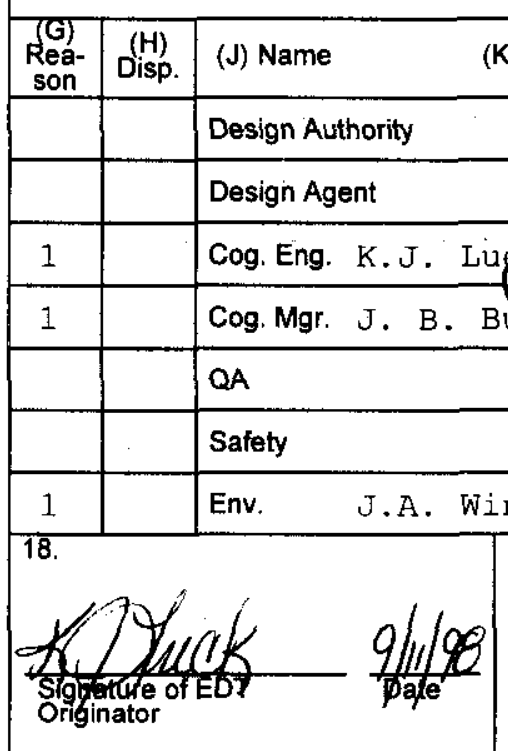

SIGNATURE/DISTRIBUTION

(See Approval Designator for required signatures)

\begin{tabular}{lll|l|l} 
K) Signature & (L) Date & (M) MSIN & $\begin{array}{c}\text { Rea- } \\
\text { son }\end{array}$ & $\begin{array}{c}(\mathrm{H}) \\
\text { Disp. }\end{array}$ \\
\hline
\end{tabular}

(J) Name

(K) Signature

(L) Date

(M) MSIN

E.M. Greager Fuipl Greage $9 / 9 / 9846-36$

R.H. Engelmarnff.S 9-9-98H6-26

R.B. Barmettlorf Ran the 16-04

D.L. Halgren DIIfladed g/3/98 L6.04

R.R. Bloom Ple gledes S6-71

D.L. Flyctes $9 / 10 / e r 55-7 i$

G.C. Triner

Authorized Representative for Receiving Organization

19.

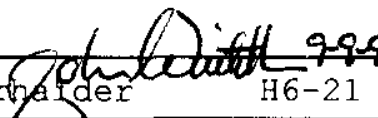

(1)

dex<smiles>CCC</smiles> 


\title{
Hanford Site Liquid Waste Acceptance Criteria
}

\author{
K. J. Lueck
}

Waste Management Federal Services of Hanford, Inc.

Richland, WA 99352

U.S. Department of Energy Contract DE-AC06-96RL13200

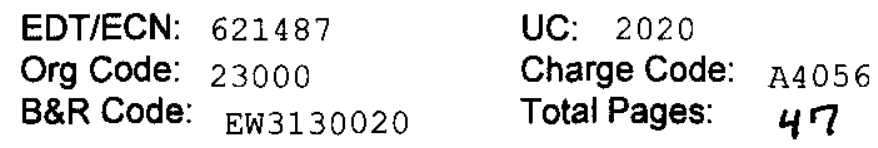

Key Words: liquid waste, acceptance criteria

Abstract: This document provides the waste acceptance criteria for liquid waste managed by Waste Management Federal Services of Hanford, Inc.

(WMH). These waste acceptance criteria address the various requirements to operate a facility in compliance with applicable environmental, safety, and operational requirements. This document also addresses the sitewide miscellaneous streams program.

TRADEMARK DISCLAIMER. Reference herein to any specific commercial product, process, or service by trade name, trademark, manufacturer, or otherwise, does not necessarily constitute or imply its endorsement, recommendation, or favoring by the United States Government or any agency thereof or its contractors or subcontractors.

Printed in the United States of America. To obtain copies of this document, contact: Document Control Services, P.O. Box 950, Mailstop H6-08, Richland WA 99352, Phone (509) 372-2420; Fax (509) 376-4989.
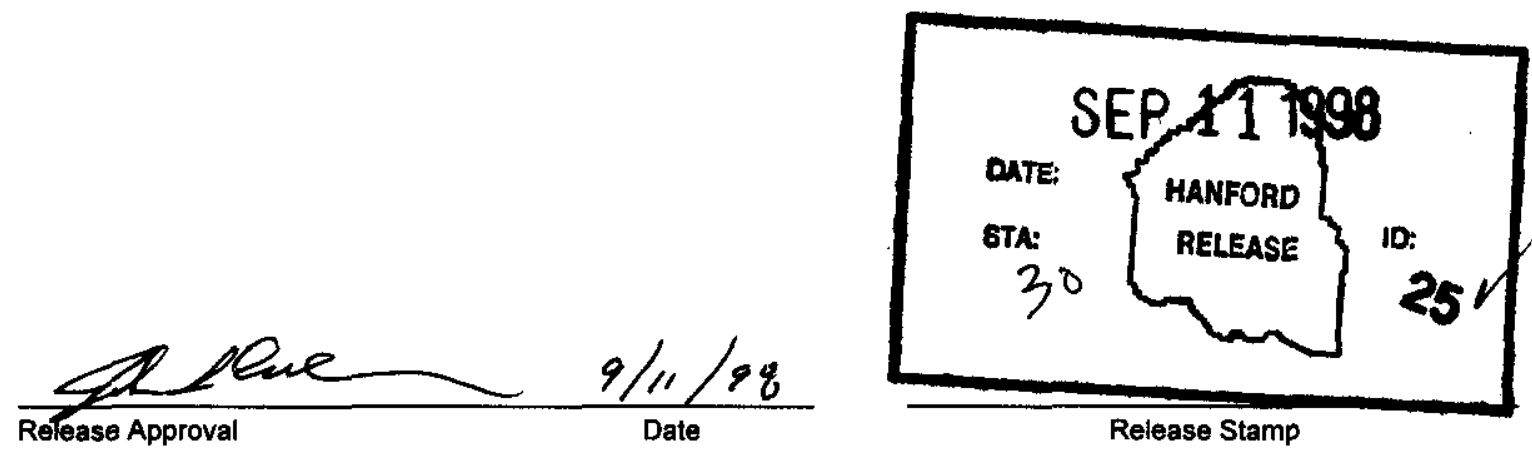

Approved For Public Release 
HNF-3172, Rev. 0

\section{Hanford Site Liquid Waste Acceptance Criteria}

September 1998

Prepared By:

Waste Management Federal Services of Hanford, Inc. 
HNF-3172, Rev. 0

This page intentionally left blank. 
HNF-3172, Rev. 0

\section{CONTENTS}

GLOSSARY $\mathrm{v}$

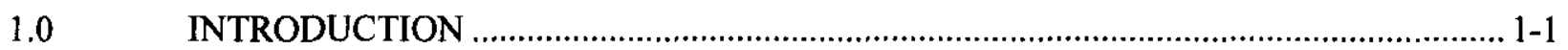

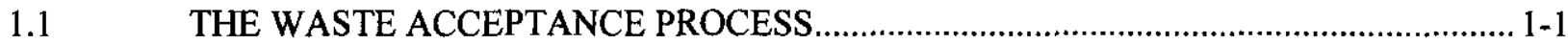

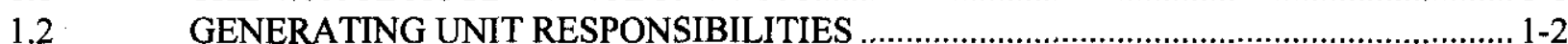

EXCEPTIONS TO THE WASTE ACCEPTANCE CRITERIA .................................... 1-2

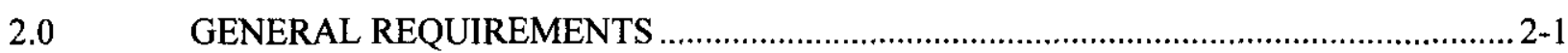

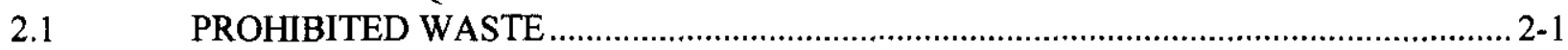

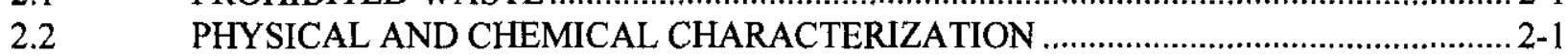

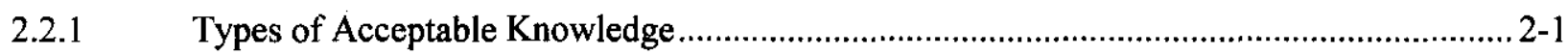

2.2.2 Acceptable Knowledge for Designation ....................................................................... 2-1

2.2.3 Acceptable Knowledge for Land Disposal Restrictions................................................2 2-2

2.2.4 Acceptable Knowledge for Facility Waste Management Requirements............................ 2-2

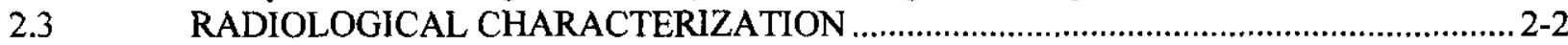

2.3.1 Identification of Major Radionuclides....................................................................... 2-2

2.3.2 Acceptable Knowledge for Establishing Radionuclide Inventory ...................................2-2

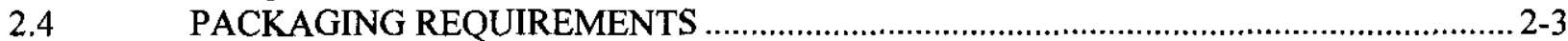

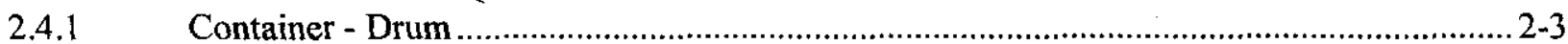

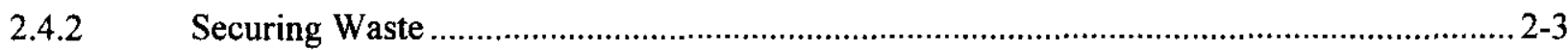

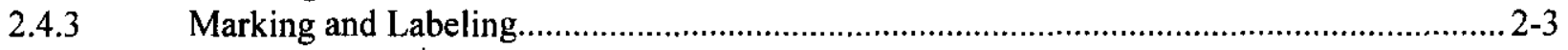

$3.0 \quad 300$ AREA TREATED EFFLUENT DISPOSAL FACILITY …................................... $3-1$

3.1 FACILITY DESCRIPTION AND FUNCTION ..................................................... $3-1$

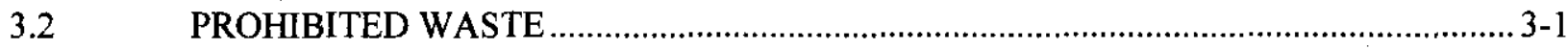

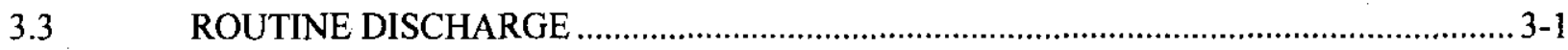

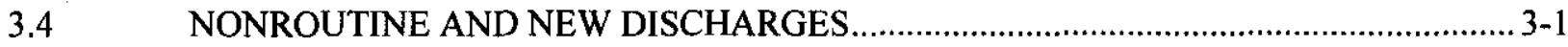

$4.0 \quad 200$ AREA EFFLUENT TREATMENT FACILITY ................................................ $4-1$

$4.1 \quad$ FACILITY DESCRIPTION AND FUNCTION

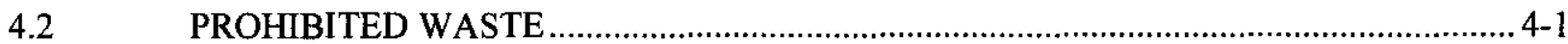

4.3 LIQUID WASTE PROFILE SHEET AND CHARACTERIZATION DATA ................... 4-1

$4.4 \quad$ PHYSICAL AND CHEMICAL CRITERIA ….......................................................... 4-2

4.4.1 Percent Solids in Liquid Waste .......................................................................... 4-2

4.4.2 LERF Liner Compatibility .............................................................................. 4-2

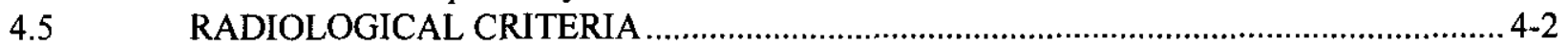

4.5.1 Total Facility Dose Equivalent Curie Limit ........................................................... 4-2

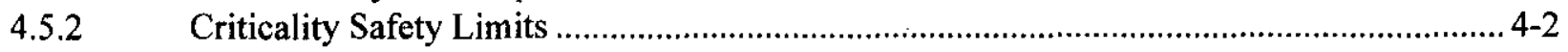

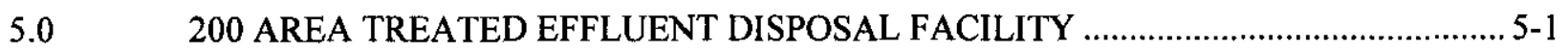

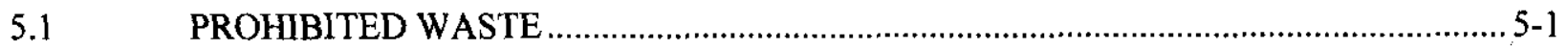

$5.2 \quad$ NONROUTINE AND NEW DISCHARGES ........................................................... $5-1$

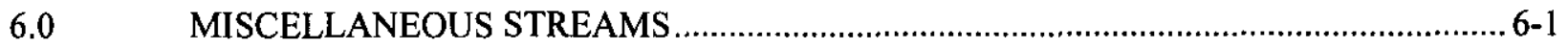

6.1 AREAS WHERE THE MISCELLANEOUS PROGRAM APPLIES .............................. 6-1

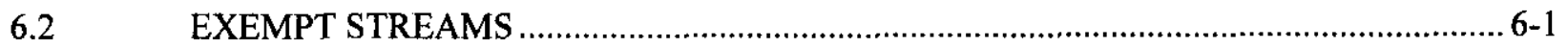


HNF-3172, Rev. 0

\section{CONTENTS (cont)}

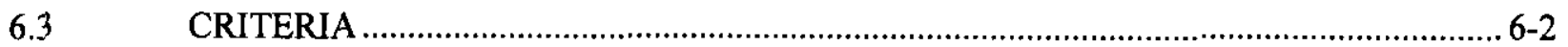

6.4 WAC 173-216 CATEGORICAL PERMITS ..................................................................

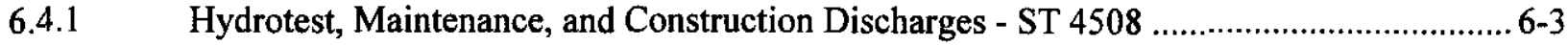

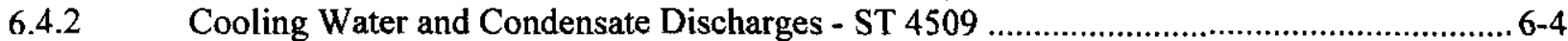

6.4.3 Storm Water Discharges - ST No. to be determined ...................................................... 6-4

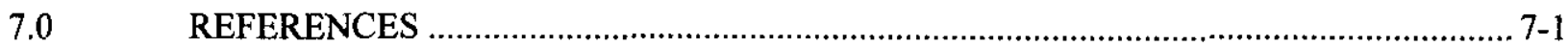

\section{APPENDICES}

A LIQUID WASTE PROFILE SHEET FOR 300 AREA TREATED EFFLUENT DISPOSAL FACILITY AND 200 AREA EFFLUENT TREATMENT

FACILITY

APP A-i

B $\quad 300$ AREA TREATED EFFLUENT DISPOSAL FACILITY …...................................... APP B-i

C 200 AREA EFFLUENT TREATMENT FACILITY AND LIQUID EFFLUENT RETENTION FACILITY APP C-i

D 200 AREA TREATED EFFLUENT DISPOSAL FACILITY APP D-i

\section{FIGURE}

Figure 1. Liquid Waste Acceptance Process Flow Diagram $1-3$ 
HNF-3172, Rev. 0

\section{GLOSSARY}

BMP

CERCLA

DCG

DOE

DOE/RL

DOT

Ecology

EPA

ETF

FDH

Gpm

GWQC

HNF

LDR

LERF

MSDS

NPDES

PCB

PHMC

RCRA

SALDS

SCA

TEDF

TSD

TSCA

WDOH

WMH

WPS best management practices

Comprehensive Environmental Response, Compensation and Liability Act of 1980

Derived Concentration Guideline

U.S. Department of Energy

U.S. Department of Energy, Richland Operations Office

U.S. Department of Transportation

Washington State Department of Ecology

U.S. Environmental Protection Agency

200 Area Effluent Treatment Facility

Fluor Daniel Hanford, Inc.

gallons per minute

Ground Water Quality Criteria

Hanford Nuclear Facility (document identifier)

land disposal restriction

Liquid Effluent Retention Facility

material safety data sheet

National Pollution Discharge Elimination System

polychlorinated biphenyls

Project Hanford Management Contract

Resource Conservation and Recovery Act of 1976

State-Approved Land Disposal Site

surface contaminated area

Treated Effluent Disposal Facility

treatment, storage, and/or disposal

Toxic Substances Control Act of 1976

Washington State Department of Health

Waste Management Federal Services of Hanford, Inc.

waste profile sheet 
HNF-3172, Rev. 0

This page intentionally left blank. 
HNF-3172, Rev. 0

\subsection{INTRODUCTION}

This document provides the waste acceptance criteria for liquid waste managed by Waste Management Federal Services of Hanford, Inc. (WMH). Liquid waste types could include dangerous, nondangerous, mixed, radioactive, and/or nonradioactive waste. These waste types hereinafter are referred to as liquid waste. These waste acceptance criteria address the various requirements to operate a facility in compliance with applicable environmental, safety, and operational requirements. This document also addresses the sitewide miscellaneous streams program.

These waste acceptance criteria apply to the following facilities: 300 Area Treated Effluent Disposal Facility (300 Area TEDF), 200 Area Effluent Treatment Facility (ETF), Liquid Effluent Retention Facility (LERF), and 200 Area Treated Effluent Disposal Facility (200 Area TEDF). For the purposes of this document, the ETF and LERF will be considered a single facility. This document also summarizes the criteria for ensuring that existing and future miscellaneous streams are in compliance with applicable regulations and permits. This document does not address the waste acceptance criteria for the 242-A Evaporator.

Generating units must comply with these criteria. Exceptions could be granted as provided in Section 1.3.

\subsection{THE WASTE ACCEPTANCE PROCESS}

The following sections describe the process for ensuring that liquid waste from the point of generation to the point of receipt, is an efficient process. A generic flowsheet of the process, Figure 1-1, describes the steps involved from the initial contact to receipt of the liquid waste.

When a generating unit either has an existing or future liquid waste that requires some type of management, the generating unit should contact WMH Generator Services. Generator Services works with the generating unit to collect all existing sampling data and process knowledge to make an initial screening to determine the best management path for the waste. At a minimum, preliminary data required for an initial screening are waste designation and radiological levels. Generally, the generating unit has adequate existing data to complete the preliminary screening without having to perform any additional sampling. If not, it is to the generating unit's advantage to contact Generator Services before any sampling of the liquid waste is performed. This could eliminate the need for resampling and reduce analytical requirements.

Once the management path has been determined, Generator Services will communicate to the generating unit representative any additional facility-specific information and/or analytical data that are required for acceptance of the liquid waste at the facility. For liquid waste being considered for acceptance at the 300 Area TEDF or ETF, a completed and certified waste profile sheet (WPS) is required (Appendix A). Verification sampling of the liquid waste may be required in some cases, for example, large volume and/or routine discharges. Verification sampling is necessary to ensure that a liquid waste continues to meet the facility-specific acceptance criteria. Generator Services also will assist in the scheduling, etc., for the actual transfer of liquid waste.

It is the responsibility of the generating unit to ensure the liquid waste shipment has all applicable shipping papers, and that the proper container is used with proper labeling. 
HNF-3172, Rev. 0

\subsection{GENERATING UNIT RESPONSIBILITIES}

Generating unit representatives are required to certify that the liquid waste has been properly designated and accurately characterized. The generating units are responsible for costs incurred by the receiving facility resulting from nonconformance with the waste acceptance criteria.

\subsection{EXCEPTIONS TO THE WASTE ACCEPTANCE CRITERIA}

Exceptions to one or more of the criteria in this document could be granted on case-by-case basis. A generating unit requesting an exception, must identify the specific requirement(s) in this document for which an exception is desired, the reason an exception is needed, and any proposed alternative methods to meet the general intent of the criteria. The request should be sent, in writing, to Generator Services.

The request will be reviewed and a determination will be made as to whether an exception could be approved by WMH, or whether U.S. Department of Energy, Richland Operations Office (DOE-RL) and/or regulatory agency approvals are required. On completion of this review, Generator Services will respond to the request from the generating unit, identifying whether the exception is granted, rejected, or requires further evaluation or clarification. 
HNF-3172, Rev. 0

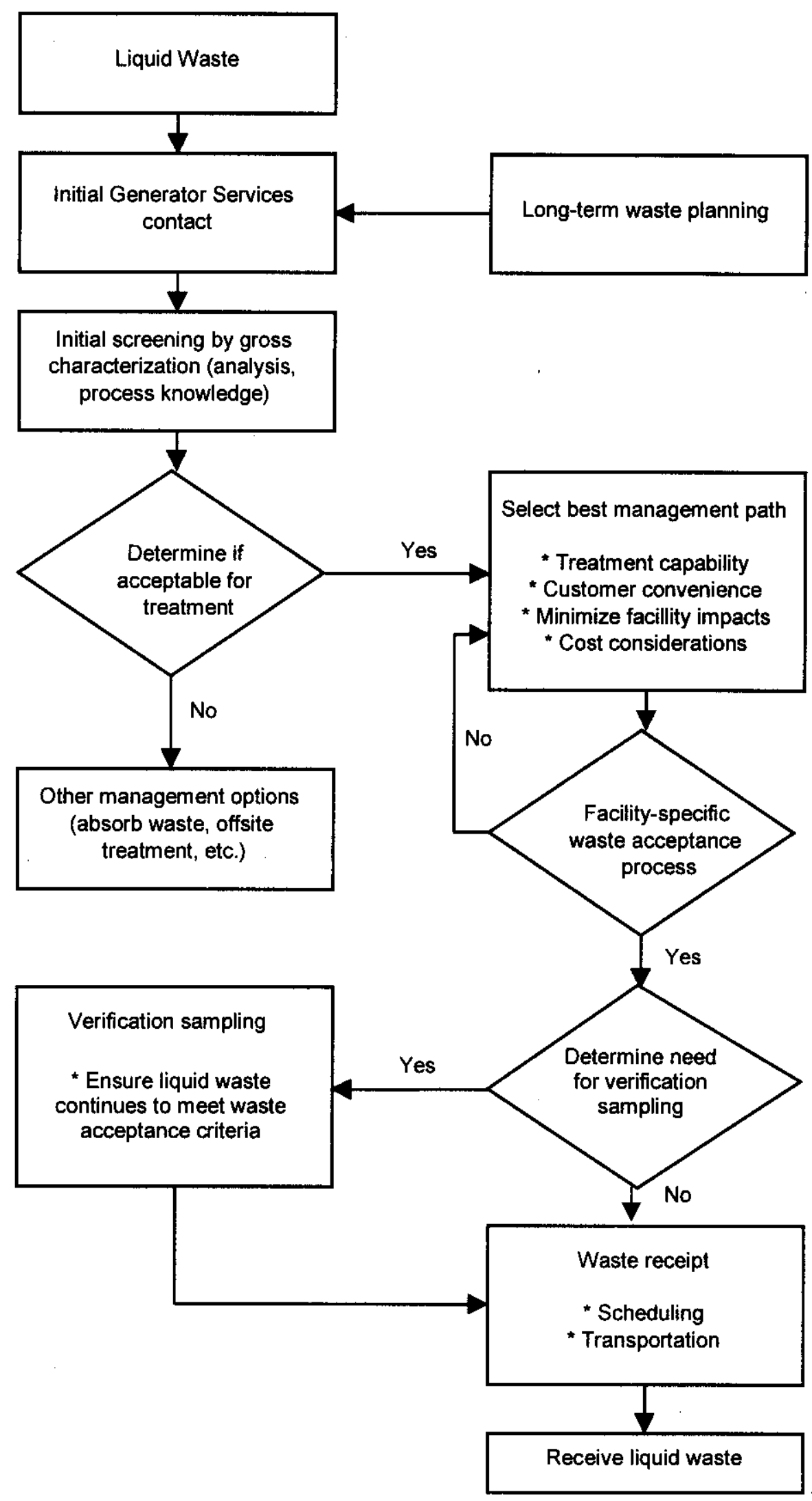

Figure 1. Liquid Waste Acceptance Process Flow Diagram. 
HNF-3172, Rev. 0

This page intentionally left blank 
HNF-3172, Rev. 0

\subsection{GENERAL REQUIREMENTS}

Certain general requirements apply to acceptance of all liquid waste. These requirements are described in the following sections.

\section{$2.1 \quad$ PROHIBITED WASTE}

The following waste is prohibited from management at the facilities addressed in this document. Additional prohibited waste that apply to an individual facility is provided in the facility-specific chapter.

- TSCA-regulated PCB waste

- Explosive liquid waste

- Unstable liquid waste

- Liquid waste that could generate toxic gases, vapors, or fumes in concentrations that reasonably could be expected to exceed occupational exposure limits and/or air emission standards

- Biohazard waste.

\subsection{PHYSICAL AND CHEMICAL CHARACTERIZATION}

The generating unit must determine the physical and chemical characteristics of the liquid waste with sufficient accuracy and detail to properly designate and manage the liquid waste in accordance with the facility-specific acceptance criteria and all applicable regulations (i.e., acceptable knowledge). The following sections describe the physical and chemical characterization requirements for waste acceptance.

\subsubsection{Types of Acceptable Knowledge}

Types of information that can be used for physical and chemical characterization include data from analysis of the liquid waste and knowledge of the materials and/or processes used to generate the waste. Acceptable knowledge requirements might be met by using the following types of information:

- Historical data

- Mass balance from a controlled process having a specified output for a specified input

- Material safety data sheet (MSDS) information

- Analytical data on the liquid waste or a liquid waste from a similar process.

The receiving facility will determine the adequacy of liquid waste characterization data provided by the generating unit.

\subsubsection{Acceptable Knowledge for Designation}

Analytical data and/or knowledge of the liquid waste must be sufficient to determine whether the waste is regulated under 40 CFR 262, 760, and/or WAC 173-303, and assigned correct waste numbers. Any toxic constituent causing a waste number to be assigned must be quantified using process knowledge and/or analytical data. 
In cases where constituents that could cause a waste to be regulated are input into a process, but are not expected to be in the waste in concentrations causing a waste to be designated, sampling and analysis must be performed to demonstrate that the constituents are below regulated limits. This requirement can be met through chemical screening and is only required for initial characterization of the liquid waste.

\subsubsection{Acceptable Knowledge for Land Disposal Restrictions}

For liquid waste that is a hazardous waste as defined in 40 CFR Part 261, waste characterization must be sufficient to establish whether the waste is a restricted waste under the land disposal restriction (LDR) provisions of 40 CFR Part 268 and, if so, to determine the applicable treatment standard(s) for that waste. In addition, for waste that is a dangerous waste as defined in WAC 173-303, characterization must be sufficient to establish which, if any, of the state LDR requirements of WAC 173-303-140 are applicable.

\subsubsection{Acceptable Knowledge for Facility Waste Management Requirements}

All liquid waste must be characterized in a manner sufficient to ensure that the waste can be managed in accordance with the facility-specific waste management requirements set forth in this document. This includes, but is not limited to, sufficient knowledge to demonstrate that the waste is not prohibited from management at the facility and to ensure that the waste can be managed safely.

\subsection{RADIOLOGICAL CHARACTERIZATION}

The major radionuclides in the liquid waste and the concentration of each major radionuclide must be established with sufficient sensitivity and accuracy to properly classify and manage the waste in accordance with the facility-specific radiological limits.

\subsubsection{Identification of Major Radionuclides}

For the purpose of the radiological criteria in this document, major radionuclides are defined as those radionuclides that meet any of the following conditions:

- Any fissionable radionuclide present in the liquid waste in quantity exceeding 0.1 gram

- Any radionuclide that accounts for more than $1 \%$ of the total radiological activity in the waste.

\subsubsection{Acceptable Knowledge for Establishing Radionuclide Inventory}

The radionuclide inventory of a liquid waste must be established using a method or a combination of methods capable of identifying and quantifying the major radionuclides present.

The following characterization methods can be used individually or in combination to establish the radionuclide inventory of the waste.

- Process knowledge - Process knowledge includes documented knowledge of the radioactive materials used and the processes contributing to the radiological content of the waste, along with historical analysis of waste and radiological contamination from the process. Process knowledge can be used to establish the suspected major radionuclides in the liquid waste. In addition, process knowledge can be used to eliminate from further consideration those radionuclides not present in sufficient concentration to be major radionuclides as defined in Section 2.3.1, as long as the basis of this determination is 
HNF-3172, Rev. 0

documented. Process knowledge alone generally is not sufficient to quantify the radionuclide inventory of the waste.

- Direct analytical data - Direct analytical data can be used to quantify the major radionuclides with adequate sensitivity and accuracy for waste classification. Analysis methods that measure gross activity (i.e., not radionuclides specific) must be used in conjunction with other methods to determine the relative concentration (scaling factors) of each suspected radionuclide, and must be corroborated periodically with radionuclide specific analysis.

- Scaling factors - Scaling factors can be used to relate the concentration of a readily measured radionuclide to more difficult to measure radionuclides.

Other methods of radiological characterization could be used, but must be clearly documented and approved by the receiving facility. Documentation of the method must include a detailed description of the method; the radionuclides identified by the method; and a discussion of precision, accuracy, quality assurance, and quality control methods.

\subsection{PACKAGING REQUIREMENTS}

WMH has tankers available for use by a generating unit. The generating unit is responsible for the tanker at the time of release from the WMH facility until the tanker is accepted back at the WMH facility. The generating unit shall meet the applicable U.S. Department of Transportation (DOT) requirements of 49 CFR for transportation of a hazardous material if applicable. The generating unit is responsible to return the tanker in the same condition in which the tanker was released. If the tanker is not returned in the same released condition, the generating unit is responsible to restore the tanker to its released condition. The scheduling of such restoration shall be negotiated between the generating unit and WMH.

\subsubsection{Container - Drum}

Containers shall be in good condition, with no visible cracks, holes, dents, bulges, pit or scale corrosion, or other damage that could compromise the integrity of the container, resulting in a safety concern for those handling the container. Packages shall meet the applicable DOT requirements of 49 CFR for transportation of hazardous material if applicable.

\subsubsection{Securing Waste}

Large heavy items must be secured in containers by bracing, blocking, or other means to prevent damage to the container during handling and transportation.

\subsubsection{Marking and Labeling}

Containers shall be properly labeled and marked per DOT requirements of 49 CFR. 
HNF-3172, Rev. 0

This page intentionally left blank. 
HNF-3172, Rev. 0

\subsection{AREA TREATED EFFLUENT DISPOSAL FACILITY}

The following criteria define baseline requirements to comply with the environmental, safety, and operational requirements for the 300 Area TEDF.

\subsection{FACILITY DESCRIPTION AND FUNCTION}

300 Area TEDF consists of a series of process units that are configured to provide treatment of a liquid waste before its discharge to the Columbia River under a National Pollution Discharge Elimination System (NPDES) permit. The 300 Area TEDF is an industrial facility, and is not allowed at this time to receive regulated hazardous waste, dangerous waste, or TSCA PCB waste.

The primary source of liquid waste is discharged to the 300 Area Process Sewer System, which includes the 300 Area Retention Process Sewer, both of which discharge to the 300 Area TEDF.

\subsection{PROHIBITED WASTE}

Facility-specific prohibited waste not listed in Section 2.1 is as follows:

- Radioactive materials greater than 1 derived concentration guideline (DCG) (DOE Order 5400.5)

- Hazardous waste, as defined by WAC 173-303

- Floor wax, or any material with similar properties that could coat detectors, plug instrument lines, or foul treatment train components

- Separable organics (separable oily liquid waste may be accepted in containers).

\subsection{ROUTINE DISCHARGE}

Routine discharges to the 300 Area TEDF are those streams that discharge continuously or at a regular frequency from the same source. Generating units that have routine discharges must meet the waste acceptance criteria given in Appendix B, or previously been approved for discharges. If there are any significant changes in the constituent loading or quantities of routine discharges, the 300 Area TEDF facility representative is notified. A generating unit of a routine discharge must comply with HNF-IP-1000, Section 3.4. Those facilities considered to have routine discharges to the 300 Area TEDF are listed in Appendix B, Table B-3.

\subsection{NONROUTINE AND NEW DISCHARGES}

A generating unit is required to complete and certify the liquid waste profile sheet (WPS) (Appendix A) with all supporting documentation and analytical data attached. The WPS must, at a minimum, include the following liquid waste information: volume, source description, major chemical components and physical characteristics, and regulatory designation per WAC 173-303 (lines 1,4,9,13).

A generating unit can use process knowledge in lieu of some analyses, as determined and approved by the 300 Area TEDF facility representative. For example, if a generating unit provides information that the process generating the liquid waste does not include or involve organic chemicals, analyses for organic 
HNF-3172, Rev. 0

compounds likely would not be necessary. Additional analyses could be required if historical information and/or process knowledge indicate that a liquid waste contains constituents not included in the list of constituents. The facility representative will work with the generating unit to determine which analyses are appropriate for characterization of the liquid waste. The generating unit also is required to meet the criteria set forth in Section 2.2. 
HNF-3172, Rev. 0

\subsection{AREA EFFLUENT TREATMENT FACILITY}

The following criteria define baseline requirements to comply with the environmental, safety, and operational requirements for ETF. In most cases, liquid waste is sent to LERF for storage before treatment and discharge through the ETF. Therefore, for the purpose of this document, the ETF and LERF are considered as a single facility. Disposal of liquids to the ETF directly, without transfer to the LERF, is handled on a case-by-case basis.

\subsection{FACILITY DESCRIPTION AND FUNCTION}

The ETF began operation in 1995 and consists of a series of process systems (treatment trains) configured to provide treatment for contaminants that might be present in liquid waste. The primary treatment train includes those process systems that remove or destroy dangerous and radioactive constituents from the liquid waste. These constituents are concentrated and dried into a powder in the secondary treatment train. The powder is containerized and transferred to a TSD unit. The treated liquid waste from the ETF is discharged to a State-Approved Land Disposal Site (SALDS) under the State Waste Discharge Permit ST 4500 .

The operation of the ETF is subject to the requirements contained in DOE Orders, and is regulated under permits and approval issued by the Washington State Department of Ecology (Ecology), Washington State Department of Health (WDOH), and the U.S. Environmental Protection Agency (EPA). The ETF can treat liquid waste regulated under RCRA, CERCLA, or DOE Orders. ETF also can treat liquid waste that is not regulated under any of these programs (i.e., nonhazardous, nonradioactive).

Because of the flexibility of the ETF/LERF, with the exception of radionuclides, there is no facility-specific acceptance criteria for inorganic or organic constituents. Liquid waste acceptability will be screened on a case-by-case basis based on concentration levels and volume.

\subsection{PROHIBITED WASTE}

Facility-specific prohibited waste not listed in Section 2.1 is as follows:

- Liquid waste designated with waste numbers other than, FOO1 through F005, F039 for leachate derived from F001 through F005 waste, D001 through D011, D018, D019, D022, D028 through D030, D033 through D036, D038 through D041, D043, state waste numbers WT01 and WT02. Liquid waste designated with other waste numbers would require modification of the Hanford Facility (HF) RCRA Permit.

- Separable organics

- Transuranic liquid waste and liquid waste that exceeds any of the radiological limits of Section 4.5

- Total fissile material mass outside the limits of a criticality exempt facility classification.

\subsection{LIQUID WASTE PROFILE SHEET AND CHARACTERIZATION DATA}

A generating unit is required to complete a signed liquid WPS (Appendix A) with all supporting documentation and analytical data attached. The WPS must, at a minimum, include the following liquid 
HNF-3172, Rev. 0

waste information: volume, source description, chemical and physical composition, regulatory designation per WAC 173-303-070, and identification of any constituents above the LDR treatment standards per 40 CFR 268.48 .

The generating unit is required to analyze the liquid waste for the constituents listed in Table C-1 of Appendix C. A generating unit could use process knowledge in lieu of some analyses, as determined and approved by the ETF representative, if process knowledge is adequate. For example, if a generating unit provides information that the process generating the liquid waste does not include or involve organic chemicals, analyses for organic compounds likely would not be necessary. Additional analyses could be required if historical information and/or process knowledge indicate that a liquid waste contains constituents not included in the list of constituents. The facility representative will work with the generating unit to determine which analyses are appropriate for characterization of the liquid waste. The generating unit also is required to meet the criteria set forth in Section 2.2.

\subsection{PHYSICAL AND CHEMICAL CRITERIA}

The following sections describe the physical and chemical criteria for acceptance of waste at ETF/LERF.

\subsubsection{Percent Solids in Liquid Waste}

Liquid waste containing greater than $1 \%$ solids may be required to be filtered through a 5 micron (nominal) filter before receipt at the ETF/LERF. Additional filtration could be required if a significant amount of suspended solids remains after 5 micron filtration.

\subsubsection{LERF Liner Compatibility}

To protect the integrity of the LERF liner(s), the compatibility of a liquid waste with the liner materials is established up front. The constituents concerned for liner compatibility, along with their limits are given in Table C-2 of Appendix C and were established in the HF RCRA Permit for LERF and ETF (Ecology 1994).

\subsection{RADIOLOGICAL CRITERIA}

The following sections describe the radiological criteria for acceptance of waste at ETF.

\subsubsection{Total Facility Dose Equivalent Curie Limit}

The ETF and LERF are termed radiological facilities. This designation is based on the dose consequences from postulated releases. Operational controls have been implemented at the ETF/LERF to maintain the dose consequences below those evaluated in the hazard category. Liquid waste accepted at LERF will be controlled so that the maximum bounding source terms are not exceeded (Table C- 2 of Appendix C).

\subsubsection{Criticality Safety Limits}

ETF/LERF has a total fissile material limit of 15 grams. Liquid waste receipt will be controlled by maintaining an inventory of the total fissile material mass within the facility. 
HNF-3172, Rev. 0

\subsection{AREA TREATED EFFLUENT DISPOSAL FACILITY}

The 200 Area TEDF consists of the piping system, along with supporting structures, components, and instrumentation that begins at the generating unit/200 Area TEDF interface and ends at the 200 Area TEDF disposal ponds. Because the 200 Area TEDF does not have any treatment or retention capacity, strict control at the generating unit interface is essential to operate the 200 Area TEDF in compliance with the State Waste Discharge Permit No. ST 4502 (ST 4502). The 200 Area TEDF can receive nondangerous, nonradioactive liquid waste that meets the requirements of ST 4502.

\subsection{PROHIBITED WASTE}

Facility-specific prohibited waste not listed in Section 2.1 is as follows.

- Radioactive materials greater than WAC 173-200, Ground Water Quality Criteria (GWQC)

- Hazardous waste, as defined by WAC-173-303.

\subsection{NONROUTINE AND NEW DISCHARGES}

For nonroutine and new discharges, the discharge must be pre-approved by the 200 Area TEDF facility representative. Once the discharge has been approved, the generating unit is required to be in compliance with the "200 Area Treated Effluent Disposal Facility Interface Control Document", HNF-SD-W049H-ICD-001 (ICD), if applicable. Any discharge or source that currently is not listed in the 200 Area ICD, must be pre-approved.

The target limits for discharges into the 200 Area TEDF are listed in Table D-1 of Appendix D. The generating unit is required to certify that no additional constituents exist in the liquid waste that would constitute a contaminant to groundwater per the requirements of WAC 173-200. 
HNF-3172, Rev. 0

This page intentionally left blank. 
HNF-3172, Rev. 0

\subsection{MISCELLANEOUS STREAMS}

On December 23, 1991, the U.S. Department of Energy, Richland Operations Office (DOE-RL) and the Washington State Department of Ecology (Ecology) agreed to adhere to the provisions of the Department of Ecology Consent Order No. DE 91NM-177 (Consent Order) (Ecology and DOE-RL, 1991). The Consent Order lists regulatory milestones for liquid effluent streams at the Hanford Site to comply with the permitting requirements of Washington Administrative Code (WAC) 173-216 (State Waste Discharge Permit Program) or WAC 173-218 (Underground Injection Control Program) where applicable.

One of the Consent Order milestones was to develop a Plan and Schedule for Disposition and Regulatory Compliance for Miscellaneous Streams (Plan and Schedule) (DOE/RL-95-93). This document was approved by Ecology on February 9, 1995. The options for disposition of miscellaneous streams were selected based on demonstrating compliance with the Hanford Federal Facility and Consent Order (Tri-Party Agreement), the Consent Order, WAC 173-216, WAC 173-218, and Revised Code of Washington 90.48 .

Contact Environmental Services, WMH, or a Generator Services representative for guidance relating to Miscellaneous Streams.

\subsection{AREAS WHERE THE MISCELLANEOUS PROGRAM APPLIES}

Applicability of the Miscellaneous Streams Program is limited to activities conducted by DOE-RL and its contractors, and excludes activities conducted by others on lands governed by leases, use permits, easements, and other agreements whereby land is used by parties other than DOE-RL or its contractors. For example, the Miscellaneous Streams Program does not apply to activities on state owned or leased lands: lands owned by the Bonneville Power Administration or lands leased to the Washington Public Power Supply System and US Ecology, and the Ashe Substation; or similarly leased lands not under the management of DOE-RL or its contractors.

The Consent Order requires that liquid effluent discharges (e.g., miscellaneous streams) comply with the requirements of WAC 173-216 and WAC 173-218. The following section describe requirements under WAC 173-216 categorical permits, discharges that are exempt of WAC 173-216 permitting, and acceptance criteria.

\subsection{EXEMPT STREAMS}

The following wastewater discharges are exempt from WAC 173-216 permitting if the discharge is managed as described.

- Industrial wastewater that is discharged to the ground for a beneficial use (e.g., irrigation, aesthetics, dust control), however, the discharges must meet the GWQC defined in WAC 173-200.

NOTE: The effluent must meet GWQC at the point of discharge unless it can be demonstrated to Ecology's satisfaction that the site-specific characteristics will degrade or attenuate contaminants before reaching the groundwater, and will not generate contaminants by discharging the wastewater into the environment (Ecology, 1996).

- Fire test water that is not contaminated 
HNF-3172, Rev. 0

- Existing steam condensate streams that discharge to injection wells registered under WAC 173-218 are exempt from WAC 173-216 permitting. No new injection well can be constructed to receive steam condensate discharges.

- Discharges to the ground due to atmospheric condensate on equipment

- Purgewater resulting from well sampling, well development, well rehabilitation, and aquifer testing must be managed according to Strategy for Handling and Disposing of Purgewater at the Hanford Site, Washington (DOE-RL 1990).

- Wastewater from washing the exterior of vehicles must be managed according to Vehicle and Equipment Wastewater Discharges (Ecology 1995).

- Discharges related to CERCLA activities are exempt from permitting and administrative requirements. However, the actions taken must meet the substantive requirements of applicable or relevant and appropriate requirements. Discharges for CERCLA activities similar to those covered under the categorical permits either will comply with agreements reached between DOE-RL and the lead regulatory agency or will meet the substantive requirements identified in the categorical permits (excluding administrative requirements such as recordkeeping and reporting.

\subsection{CRITERIA}

The Plan and Schedule defined three criteria for identifying liquid effluent streams that potentially could affect groundwater quality. For a new stream that meets any of the following criteria, the generating unit must evaluate and implement best management practices (BMPs).

- Streams discharging within a surface contaminated area (SCA).

SCAs are defined as those near-surface soils contaminated with dangerous and/or radioactive waste. The concern with discharging liquid effluents directly to a SCA is the potential for the existing contaminants in the soil to migrate to groundwater.

- Potentially contaminated streams.

The acceptable effluent quality is derived by evaluating the potential for constituents listed in the GWQC (Table 1 of WAC 173-200) to enter the source water and cause the GWQC to be exceeded. Liquid effluents originating from sources with physical and/or administrative barriers to prevent contaminants from entering the stream are not considered to have a potential for contaminants. Wastewater unaltered except for temperature (e.g., steam condensate, uncontaminated storm water, noncontact cooling water) is not considered to have the potential for contaminants exceeding the GWQC.

- Streams discharging within 91 meters of an active or inactive crib, ditch, or trench used for the disposal of dangerous and/or radioactive contaminants.

Borehole drilling on the Hanford Site has shown that existing contaminants in the soil column have the potential to migrate within a 91-meter radius of the discharge point. Miscellaneous streams discharging within this 91-meter radius have the potential to drive the existing contamination into the groundwater. 
HNF-3172, Rev. 0

\subsection{WAC 173-216 CATEGORICAL PERMITS}

Addressed in the following sections are categorical permits covering the Miscellaneous Stream discharges to the soil column on the Hanford Site.

\subsubsection{Hydrotest, Maintenance, and Construction Discharges - ST 4508}

Discharges covered under ST 4508 also must meet the requirements of a pollution prevention and BMP plan (BMP Plan) (DOE/RL-97-67). A discharge not covered previously by the BMP Plan could be added if a written request is submitted to and approved by Ecology.

Types of discharges covered under ST 4508 include the following:

- Hydrotesting discharges, which include hydrotesting of a system or component and development testing

- Maintenance discharges, which include drainage and flushing activities

- Construction discharges, which include concrete curing and pressure washing activities.

Conditions on activities covered under ST 4508 include the following:

- Each discharge must be less than 10 gallons per minute (gpm) averaged annually. Annual average flow is calculated for each discharge as total gallons discharged in a calendar year divided by the number of minutes in that year.

- Each discharge must be less than $150 \mathrm{gpm}$ instantaneously.

- Each discharge must meet WAC 173-200 GWQC unless the discharge is expected to have a contaminant that exceeds the GWQC solely because the source water has a contaminant that exceeds one or more of the GWQC. Also, discharges that exceed the GWQC at the effluent, but are prevented from impacting the groundwater quality, would be covered under this permit.

If a planned discharge meets all permit conditions except the $150 \mathrm{gpm}$ instantaneous limits and is less than $1,000 \mathrm{gpm}$, a letter can be written to Ecology to request that the planned discharge be covered under ST 4508. Ecology has included a blanket approval under ST 4508 for drinking water line flushes. Flushing activities are allowed to exceed the $150 \mathrm{gpm}$ limit for up to 20 minutes and at no time allowed to exceed $1,000 \mathrm{gpm}$.

ST 4508 also allows discharges to exceed the GWQC if the contaminant in the discharge is below $110 \%$ of the contaminant levels in the designated source water or if discharge BMPs prevent impacts to the groundwater quality. The BMPs necessary to prevent impacts to the groundwater quality are specified in the BMP Plan (DOE/RL-97-67).

ST 4508 requires that every discharge have an assigned responsible person on site who is familiar with the section of the BMP Plan that applies to the discharge. This responsible person confirms compliance with the BMP Plan and should be prepared to answer any Ecology questions in the event of an inspection.

ST 4508 requires the annual reporting of all significant discharges. A significant discharge is any single discharge greater than 14,500 gallons in a 24-hour period or any single discharge greater than 50,000 gallons in a calendar year. Information required for significant discharges include the type and date of discharge, location, source water, additives, total volume, flowrate, soil loading rate, name of assigned 
HNF-3172, Rev. 0

responsible person, and any other pertinent information. Logs of significant discharges will be consolidated by Environmental Services, of Waste Management Federal Services of Hanford, Inc and submitted to Ecology by February 15 of each year.

\subsubsection{Cooling Water and Condensate Discharges - ST 4509}

Discharges covered under ST 4509 also must meet the requirements of the BMP Plan. A discharge previously not covered by the Plan could be added if a written request is submitted to and approved by Ecology.

Types of activities covered under ST 4509 include the following:

- Cooling water discharges, which include activities related to cooling parts of heat generating systems. Systems using cooling water include air compressors, diesel engines, air conditioning, ventilation, evaporative cooling, and ice machines

- Condensate discharges, which include discharges from systems such as steam lines, steam heating systems, air compressors, air conditioning, ventilation, and ice machines

- Other miscellaneous discharges, which include discharges from pump leaks, valve wastewater, water tank overflow, and quench tanks.

Conditions on activities covered under ST 4509 include the following:

- Each discharge must be less than 10 gpm averaged annually. Annual average flow is calculated for each discharge as total gallons discharged in a calendar year divided by the number of minutes in that year

- Each discharge must be less than $150 \mathrm{gpm}$ instantaneously

- Each discharge must meet WAC 173-200 GWQC unless the discharge is expected to have a contaminant that exceeds the GWQC solely because the source water has a contaminant that exceeds one or more of the GWQC. Also, discharges that exceed the GWQC at the effluent, but are prevented from impacting the groundwater quality, would be covered under this Permit.

ST 4509 also allows discharges to exceed the GWQC if the contaminant in the discharge is below $110 \%$ of the contaminant levels in the designated source water or if discharge BMPs prevent impact to groundwater quality. The BMPs necessary to prevent impacts to the groundwater quality are specified in the BMP Plan (DOE/RL-97-67).

ST 4509 requires that every discharge have an assigned responsible person on site who is familiar with the section of the BMP Plan that applies to the discharge. This responsible person confirms compliance with the BMP Plan and should be prepared to answer any Ecology questions in the event of an inspection.

\subsubsection{Storm Water Discharges - ST No. to be determined}

A WAC 173-216 categorical permit application for storm water discharges is scheduled to be submitted to Ecology by September 30, 1998. 


\subsection{REFERENCES}

DOE Order 5400.5, "Radiation Protection of the Public and the Environment".

DOE-RL, 1990, Letter from R.D. Izatt to President, HEHF; General Manager, KEH; Director, PNL; President, WHC, "Strategy for Handling and Disposing of Purgewater at the Hanford Site, WA., 90 ERB-076, August 9, 1990.

DOE-RL-95-93, Plan and Schedule for Disposition and Regulatory Compliance for Miscellaneous Stream, December 1994, U.S. Department of Energy Richland Operations Office, Richland, Washington

DOE-RL-97-03, Hanford Facility Dangerous Waste Permit Application, Liquid Effluent Treatment Facility and 200 Area Effluent Treatment Facility, U.S. Department of Energy Richland Operations Office, Richland, Washington.

DOE-RL-97-67, Pollution Prevention and Best Management Practices Plan for State Waste Discharge Permits ST 4508 and ST 4509, U.S. Department of Energy Richland Operations Office, Richland, Washington.

Ecology, 1995, "Vehicle and Equipment Wastewater Discharges", WQ-R-95_56, Washington State Department of Ecology, Olympia, Washington.

Ecology, 1995, "State Waste Discharge Permit No. ST 4500, amended for 200 Area Effluent Treatment Facility, Hanford Facility", Washington State Department of Ecology, Olympia, Washington

Ecology, 1995, "State Waste Discharge Permit No. ST 4502, for 200 Area Treated Effluent Disposal Facility, Hanford Facility", Washington State Department of Ecology, Olympia, Washington

Ecology, 1997, "State Waste Discharge Permit No. ST 4508, for Hydrotest Maintenance, and Construction Discharge Locations on the Hanford Site", Washington State Department of Ecology, Olympia, Washington.

Ecology, 1998, "State Waste Discharge Permit No. ST 4509, for Cooling Water and Condensate Discharge Locations on the Hanford Site", Washington State Department of Ecology, Olympia, Washington.

EPA, 1994, "National Pollution Discharge Elimination System Permit No. WA-002591-7, for the 300 Area Treated Effluent Disposal Facility", U.S. Environmental Protection Agency, Washington, D.C.

HNF-IP-1000, "300 Area Liquid Effluent Facilities Administration", Waste Management Federal Services of Hanford, Inc., Richland, Washington.

HNF-SD-LEF-ASA-002, "Liquid Effluent Retention Facility Auditable Safety Analysis", Waste Management Federal Services of Hanford, Inc., Richland, Washington, September 1997.

HNF-SD-W049H-ICD-001, "200 Area Treated Effluent Disposal Facility Interface Control Document", Waste Management Federal Services of Hanford, Inc., Richland, Washington. 
HNF-3172, Rev. 0

WDNR, 1994, "Aquatic Lands Sewer Outfall Lease No. 20-013357, for the 300 Area Treated Effluent Disposal Facility", Washington Department of Natural Resources, Washington 
HNF-3172, Rev. 0

APPENDIX A

LIQUID WASTE PROFILE SHEET FOR

300 AREA TREATED EFFLUENT DISPOSAL FACILITY AND

200 AREA EFFLUENT TREATMENT FACILITY 
HNF-3172, Rev. 0

This page intentionally left blank. 
HNF-3172, Rev. 0

\section{Liquid Waste Profile Sheet \\ For 300 Area TEDF and 200 Area ETF}

\begin{tabular}{|c|c|c|c|c|}
\hline \multicolumn{2}{|c|}{ Generating Facility/Location } & \multicolumn{3}{|l|}{ Facility Manager } \\
\hline \multicolumn{2}{|c|}{ Technical Contact } & \multicolumn{3}{|c|}{ Environmental Compliance Officer } \\
\hline \multicolumn{5}{|c|}{ DOE Point of Contact } \\
\hline \multicolumn{5}{|c|}{ General Waste Information } \\
\hline 1 & \multicolumn{4}{|c|}{ Describe source of liquid waste and process generating the waste } \\
\hline 2 & \multicolumn{2}{|c|}{ Was the liquid waste generated on the Hanford Site? } & Yes & No \\
\hline 3 & \multicolumn{2}{|c|}{ Is the liquid waste from a CERCLA or state mandated clean up? } & Yes & No \\
\hline \multirow[t]{2}{*}{4} & \multicolumn{2}{|c|}{$\begin{array}{l}\text { Is the liquid waste a dangerous or hazardous waste ( } 40 \text { CFR Part } 261 \text { or } \\
\text { WAC 173-303-070)? }\end{array}$} & Yes & No \\
\hline & \multicolumn{4}{|c|}{ If yes, identify all hazardous/dangerous listed and characteristic waste number(s) (e.g., D,F,K, etc.). } \\
\hline \multirow[t]{2}{*}{5} & \multicolumn{2}{|c|}{ Do any state-only waste numbers apply to the liquid waste? } & Yes & No \\
\hline & \multicolumn{4}{|c|}{ If yes, identify state waste number(s) and explain designation. } \\
\hline \multirow[t]{2}{*}{6} & \multicolumn{2}{|c|}{$\begin{array}{l}\text { Is any constituent in the liquid waste above its Land Disposal Restriction (LDR) } \\
\text { Treatment Standard (40 CFR 268)? }\end{array}$} & Yes & No \\
\hline & \multicolumn{4}{|c|}{ If yes, list constituent(s) above its LDR. } \\
\hline \multirow[t]{7}{*}{7} & \multicolumn{2}{|c|}{ Does the liquid waste contain PCBs? If no skip to question \#8. } & Yes & No \\
\hline & \multicolumn{2}{|c|}{ Is the PCB contamination from a regulated TSCA source? } & Yes & No \\
\hline & \multicolumn{4}{|l|}{ If yes, identify regulated TSCA source. } \\
\hline & \multicolumn{2}{|c|}{ Is the PCB contamination from a WAC 173-303 source with waste number W001? } & Yes & No \\
\hline & \multicolumn{4}{|c|}{ If yes, identity regulated W001 source. } \\
\hline & \multicolumn{2}{|l|}{ Is the $\mathrm{PCB}$ regulated as persistent by WAC $173-303 ?$} & Yes & No \\
\hline & \multicolumn{4}{|l|}{ If yes, identify waste number? } \\
\hline
\end{tabular}


HNF-3172, Rev. 0

Liquid Waste Profile Sheet (continued)

\begin{tabular}{|c|c|c|c|c|c|}
\hline \multicolumn{6}{|c|}{ Shipping/Transportation Information } \\
\hline 8 & \multicolumn{5}{|c|}{ Current storage container of liquid waste (e.g., sump, tank, drum, etc.). } \\
\hline \multirow[t]{2}{*}{9} & \multirow[t]{2}{*}{ Discharge/shipment frequency. } & Batch & \multicolumn{3}{|l|}{ Total volume: } \\
\hline & & Continuous & Volume per month: & & \\
\hline & \multicolumn{5}{|c|}{ State method of shipment of liquid waste (e.g., process sewer, tanker, drum, etc.). } \\
\hline \multirow{2}{*}{$\frac{10}{11}$} & \multicolumn{3}{|c|}{ Is the liquid waste DOT hazardous material? } & Yes & No \\
\hline & \multicolumn{5}{|l|}{ State proper shipping name: } \\
\hline 12 & \multicolumn{5}{|c|}{ State CERCLA reportable quantity ( $R Q$ ) and unit (if applicable): } \\
\hline 13 & \multicolumn{5}{|c|}{$\begin{array}{l}\text { Attach all applicable information and analytical data. If multiple sets of analytical data are available, } \\
\text { provide a table giving average and maximum concentrations of each constituent. }\end{array}$} \\
\hline \multicolumn{6}{|c|}{$\begin{array}{l}\text { I hereby certify that all information submitted on the Liquid Waste Profile contains true and accurate descriptions } \\
\text { of this waste, and all attached documents were prepared under my direction or supervision in accordance with a } \\
\text { system designed to ensure that qualified personnel properly gather and evaluate the information submitted. Based } \\
\text { on my inquiry of the persons who manage the system, or those persons directly responsible for gathering } \\
\text { information, the information submitted is, to the best of my knowledge and belief, true, accurate, and complete. } \\
\text { All relevant information regarding known or suspected hazards in the possession of the generating unit has been } \\
\text { disclosed. }\end{array}$} \\
\hline Sign & ture of Manager or Director: & & $\mathrm{Da}$ & & \\
\hline
\end{tabular}


HNF-3172, Rev. 0

\section{APPENDIX B}

300 AREA TREATED EFFLUENT DISPOSAL FACILITY 
HNF-3172, Rev. 0

This page intentionally left blank. 
HNF-3172, Rev. 0

TABLE B-1: 300 Area TEDF Acceptance Criteria.

\begin{tabular}{|c|c|c|}
\hline Constituent & Units & Limit \\
\hline Bis(ethylhexyl) phthalate & $\mathrm{ug} / \mathrm{L}$ & 80 \\
\hline Bromodichloromethane & $\mathrm{ug} / \mathrm{L}$ & 4 \\
\hline Chlorodifluormethane & $\mathrm{ug} / \mathrm{L}$ & 7 \\
\hline Chloroform & $\mathrm{ug} / \mathrm{L}$ & 34 \\
\hline 1,1 - Dichloroethane & $\mathrm{ug} / \mathrm{L}$ & 7 \\
\hline Methylene chloride & $\mathrm{ug} / \mathrm{L}$ & 5 \\
\hline Tetrachloroethylene & $\mathrm{ug} / \mathrm{L}$ & 9 \\
\hline Toluene & $\mathrm{ug} / \mathrm{L}$ & 9 \\
\hline 1,1,1 - Trichloroethane & $\mathrm{ug} / \mathrm{L}$ & 9 \\
\hline Trichloroethylene & $\mathrm{ug} / \mathrm{L}$ & 3 \\
\hline Aluminum & $\mathrm{ug} / \mathrm{L}$ & 418 \\
\hline Ammonia (total) & $\mathrm{ug} / \mathrm{L}$ & 1,800 \\
\hline Arsenic & $\mathrm{ug} / \mathrm{L}$ & 10 \\
\hline Beryllium & $\mathrm{ug} / \mathrm{L}$ & 30 \\
\hline Cadmium & $\mathrm{ug} / \mathrm{L}$ & 10 \\
\hline Copper & $\mathrm{ug} / \mathrm{L}$ & 80 \\
\hline Chromium & $\mathrm{ug} / \mathrm{L}$ & 50 \\
\hline Cyanide & $\mathrm{ug} / \mathrm{L}$ & 50 \\
\hline Iron & $\mathrm{ug} / \mathrm{L}$ & 1,460 \\
\hline Lead & $\mathrm{ug} / \mathrm{L}$ & 60 \\
\hline Manganese & $\mathrm{ug} / \mathrm{L}$ & 60 \\
\hline Mercury & $\mathrm{ug} / \mathrm{L}$ & 3 \\
\hline Nickel & $\mathrm{ug} / \mathrm{L}$ & 60 \\
\hline Nitrite & $\mathrm{ug} / \mathrm{L}$ & 400 \\
\hline Selenium & $\mathrm{ug} / \mathrm{L}$ & 7 \\
\hline Silver & $\mathrm{ug} / \mathrm{L}$ & 20 \\
\hline Zinc & $\mathrm{ug} / \mathrm{L}$ & 210 \\
\hline Total organic carbon (TOC) & $\mathrm{mg} / \mathrm{L}$ & 20 \\
\hline Coliform & MPN/10 & 146 \\
\hline $\mathrm{PH}$ & - & $6-11$ \\
\hline Suspended solids & $\mathrm{ug} / \mathrm{L}$ & 9,000 \\
\hline Toxic pollutants (not otherwise & $\mathrm{ug} / \mathrm{L}$ & 100 \\
\hline Alpha activity & $\mathrm{pCi} / \mathrm{L}$ & 15 \\
\hline Beta activity & $\mathrm{pCi} / \mathrm{L}$ & 50 \\
\hline Gamma energy analysis & $\mathrm{pCi} / \mathrm{L}$ & 9,000 \\
\hline Tritium & $\mathrm{pCi} / \mathrm{L}$ & 20,000 \\
\hline Radium (total) & $\mathrm{pCi} / \mathrm{L}$ & 0.4 \\
\hline
\end{tabular}

$\mathrm{pCi} / \mathrm{L}=$ picocuries per liter.

$\mathrm{ug} / \mathrm{L}=$ micrograms per liter . 
TABLE B-2: Toxic Pollutants.

\begin{tabular}{|c|c|c|c|c|c|}
\hline Chemical Compound & CAS \# & Chemical Compound & CAS\# & Chemical Compound & CAS \# \\
\hline Antimony & 7440360 & Arsenic & 7440382 & Beryllium & 7440417 \\
\hline Cadmium & 7440439 & Chromium (III) & 16065831 & Chromium (VI) & 18540299 \\
\hline Copper & 7440508 & Lead & 7439921 & Mercury & 7439976 \\
\hline Nickel & 7440020 & Selenium & 7782492 & Silver & 7440224 \\
\hline Thallium & 7440280 & Zinc & 7440666 & Cyanide & 57125 \\
\hline Asbestos & 1332214 & $2,3,7,8$ - TCDD (dioxin) & 1746016 & Acrolein & 107028 \\
\hline Acrylonitrile & 107131 & Benzene & 71432 & Bromoform & 75252 \\
\hline Carbon tetrachloride & 56235 & Chlorobenzene & 108907 & Chlorodibromethane & 124481 \\
\hline Chloroethane & 75003 & 2-Chloroethylvinyl ether & 110758 & Chloroform & 67663 \\
\hline Dichlorobromethane & 75274 & 1,1-Dichloroethane & 75343 & 1,2-Dichloroethane & 107062 \\
\hline 1,1-Dichloroethylene & 75354 & 1,2-Dichloropropane & 78875 & 1,3-Dichloropropylene & 542756 \\
\hline Ethylbenzene & 100414 & Methyl bromide & 74839 & Methyl chloride & 74873 \\
\hline Methylene chloride & 75092 & 1,1,2,2-Tetrachloroethane & 79345 & Tetrachloroethylene & 127184 \\
\hline Toluene & 108883 & 1,2-Trans-Dichloroethylene & 156605 & 1,1,1-Trichloroethane & 71556 \\
\hline 1,1,2-Trichloroethane & 79005 & Trichloroethylene & 79016 & Vinyl chloride & 75014 \\
\hline 2-Chlorophenol & 95578 & 2,4-Dichlorophenol & 120832 & 2,4-Dimethylphenol & 105679 \\
\hline 2-Methyl-4,6-dinitrophenol & 534521 & 2,4-Dinitrophenol & 51285 & 2-Nitrophenol & 88755 \\
\hline 4-Nitrophenol & 100027 & 3-Methyl-4-chlorophenol & 59507 & Pentachlorophenol & 87865 \\
\hline Phenol & 108952 & 2,4,6-Trichlorophenol & 88062 & Acenaphthene & 83329 \\
\hline Acenaphthylene & 208968 & Anthracene & 120127 & Benzidine & 92875 \\
\hline Benzo(a)anthracene & 56553 & Benzo(a)pyrene & 50328 & Benzo(b)fluorathene & 205992 \\
\hline Benzo(g,h,i)perylene & 191242 & Benzo(k)fluoranthene & 207089 & Bis(2-Chloroethoxy)methane & 111911 \\
\hline Bis(2-chlorethyl)ether & 111444 & Bis(2-chloroisopropyl)ether & 108601 & Bis(2-ethylhexyl)phthalate & 117817 \\
\hline 4-Bromophenyl phenyl ether & 101553 & Butylbenzyl phthalate & 85687 & 2-Chloronaphthalene & 91587 \\
\hline 4-Chlorophenyl phenyl ether & 7005723 & Chrysene & 218019 & Dibenzo(a,h)anthracene & 53703 \\
\hline 1,2-Dichlorobenzene & 95501 & 1,3-Dichlorobenzene & 541731 & 1,4-Dichlorobenzene & 106467 \\
\hline 3,3'-Dichlorobenzidine & 91941 & Diethyl phthalate & 84662 & Diemthyl phthalate & 131113 \\
\hline Di-n-butyl phthalate & 84742 & 2,4-Dinitrotoluene & 121142 & 2,6-Dinitrotoluene & 606202 \\
\hline Di-n-Octyl phthalate & 117840 & 1,2-Dipenylhydrazine & 122667 & Fluoranthene & 206440 \\
\hline Fluorene & 867373 & Hexachlorobenzene & 118741 & Hexachlorobutadiene & 87683 \\
\hline Hexachlorocyclopentadiene & 77474 & Hexachloroehtane & 67721 & Indeno(1,2,3-cd)pyrene & 193395 \\
\hline Isophorone & 78591 & Napthalene & 91203 & Nitrobenzene & 98953 \\
\hline N-Nitrosodimethylamine & 62759 & N-Nitrosodi-n-propylamine & 621647 & N-Nitrosodiphenylamine & 86306 \\
\hline Phenanthrene & 85018 & Pyrene & 129000 & 1,2,4-Trichlorobenzene & 120821 \\
\hline Aldrin & 309002 & alpha-BHC & 319846 & beta-BHC & 319857 \\
\hline Gamma-BHC & 58899 & delta-BHC & 319868 & Chlordane & 57749 \\
\hline 44'-DDT & 50293 & 4,4'-DOE & 72559 & 4,4'-DDD & 72548 \\
\hline Dieldrin & 60571 & alpha-Endosulfan & 959988 & beta-Endosulfan & 33213659 \\
\hline Endosulfan & 1031078 & Endrin & 72208 & Endrin aldehyde & 7421934 \\
\hline Heptachlor & 76448 & Heptachlor epoxide & 1024573 & PCB-1242 & 53469219 \\
\hline PCB-1254 & 11097691 & PCB-1221 & 11104282 & PCB-1232 & 11141165 \\
\hline PCB-1248 & 12672296 & PCB-1260 & 11096825 & PCB-1016 & 12674112 \\
\hline Toxaphene & 8001352 & & & & \\
\hline
\end{tabular}

CAS \# = Chemicals Abstract Service number. 
HNF-3172, Rev. 0

TABLE B-3: Facilities Connected to 300 Area Process Sewer, August 1998.

\begin{tabular}{|c|c|c|c|}
\hline \multicolumn{2}{|c|}{ Building } & \multicolumn{2}{|c|}{ Building } \\
\hline $303 \mathrm{~J}$ & Material Storage Building & 333 & N Fuels Fabrication Facility \\
\hline 304 & Uranium Concretion Facility & 336 & High Bay Testing Facility \\
\hline 305 & Engineering Test Facility & 337 & Technical Management Center \\
\hline $305 \mathrm{~B}$ & Hazardous Waste Storage Facility & $337 \mathrm{~B}$ & High-Bay Service Wing \\
\hline $306 \mathrm{E}$ & $\begin{array}{l}\text { Development, Fabrication, and Test } \\
\text { Laboratory }\end{array}$ & 338 & Fabrication Shop \\
\hline $306 \mathrm{~W}$ & Materials Development Laboratory & 340 & Waste Handling Facility \\
\hline 309 & Test Engineering Facility & 382 & Pumphouse \\
\hline 311 & Tank Farm & 382 & B,C,D Water Storage Tanks \\
\hline 313 & $\begin{array}{l}\text { N Fuel Manufacturing Support } \\
\text { Facility }\end{array}$ & $3701 \mathrm{U}$ & Office Building \\
\hline 314 & Engineering Development Laboratory & 3704 & Insulators Storage \\
\hline 315 & Water Filter Plant & 3705 & Photography Building \\
\hline 318 & Radiological Calibration Laboratory & $3707 \mathrm{C}$ & $\begin{array}{l}\text { Safeguards and Security Maintenance } \\
\text { Shop }\end{array}$ \\
\hline 320 & Physical Science Laboratory & 3708 & Radioanalytical Laboratory \\
\hline 323 & Mechanical Properties Laboratory & 3709 & Paint Shop \\
\hline 324 & $\begin{array}{l}\text { Waste Technology Engineering } \\
\text { Laboratory }\end{array}$ & 3716 & Storage \\
\hline 325 & Applied Chemistry Laboratory & 3717 & Spare Parts Warehouse \\
\hline 326 & Material Science Laboratory & $3717 \mathrm{~B}$ & Calibration Laboratory \\
\hline 327 & Post Irradiation Test Laboratory & 3720 & $\begin{array}{l}\text { Chemistry and Metal Science } \\
\text { Laboratory }\end{array}$ \\
\hline 329 & Chemical Science Laboratory & 3730 & Gamma Irradiation Facility \\
\hline 331 & Life Science Laboratory 1 & $3745 \mathrm{~A}$ & Electron Accelerator Facility \\
\hline $331 \mathrm{D}$ & Biomagnetic Laboratory & $3745 \mathrm{~B}$ & Positive Ion Accelerator Facility \\
\hline $331 \mathrm{E}$ & Greenhouse & $3746 \mathrm{~A}$ & Radiological Physics Laboratory \\
\hline $331 \mathrm{~J}$ & Incinerator & & \\
\hline
\end{tabular}


HNF-3172, Rev. 0

This page intentionally left blank. 
HNF-3172, Rev. 0

APPENDIX C

200 AREA EFFLUENT TREATMENT FACILITY AND

LIQUID EFFLUENT RETENTION FACILITY 
HNF-3172, Rev. 0

This page intentionally left blank. 
HNF-3172, Rev. 0

TABLE C-1: Required Analytes for 200 Area Effluent Treatment Facility/ Liquid Effluent Retention Facility.

\begin{tabular}{|c|c|c|c|}
\hline \multicolumn{4}{|c|}{ Organics } \\
\hline Constituent & Constituent & Constituent & Constituent \\
\hline $\begin{array}{ll}\text { Acetone } & (67-64-1)\end{array}$ & Benzene $\quad(71-43-2)$ & 1-Butyl alcohol (71-36-3) & Carbon tetrachloride $\quad(56-23-5)$ \\
\hline Chlorobenzene $\quad(108-90-7)$ & Chloroform & 1,2-Dichloroethane (107-06-2) & 1,2-Dichloroethene \\
\hline 1,1-Dichloroethylene (75-35-4) & 2-Hexanone & Methylene chloride $\quad(75-09-2)$ & Methyl ethyl ketone \\
\hline 2-Pentanone $\quad(107-87-9)$ & $\begin{array}{l}\text { Tetrachloroethylene } \\
\qquad(127-18-4)\end{array}$ & $\begin{array}{l}\text { Methyl isobutyl ketone } \\
\qquad(108-10-1)\end{array}$ & Tetrahydrofuran \\
\hline$(108-88-3)$ & 1,1,1-Trichloroethane & 1,1,2-Trichloroethane $(79-00-5)$ & Trichloroethylene \\
\hline$(1330-20-7)$ & $\begin{array}{l}\text { Vinyl chloride } \\
\text { 4) }\end{array}$ & Acetophenone & Benzyl alcohol \\
\hline 2-Butoxyethanol & Cresol $(o, p, m) \quad(1319-77-3)$ & 1,4-dichlorobenzene $(106-46-7)$ & Dimethylnitrosamine \\
\hline 2,4-Dinitrotoluene & $\begin{array}{l}\text { Di-n-octyl phthalate } \\
(117-84-0)\end{array}$ & Hexachloroethane $\quad(67-72-1)$ & Naphthalene \\
\hline \multicolumn{4}{|l|}{ Tributyl phosphate (126-73-8) } \\
\hline \multicolumn{4}{|c|}{ Inorganic and General Chemistry } \\
\hline Constituent/Parameter & Constituent/Parameter & Constituent/Parameter & Constituent/Parameter \\
\hline Aluminum $\quad(7429-90-5)$ & Antimony $\quad(7440-36-0)$ & $\begin{array}{ll}\text { Arsenic } & (7440-38-2) \\
\end{array}$ & Barium $\quad(7440-39-3)$ \\
\hline Beryllium $\quad(7440-41-7)$ & $(7440-43-9)$ & $(7440-70-2)$ & $(7440-47-3)$ \\
\hline Copper $(7440-50-8)$ & $(7439-89-6)$ & $(7439-92-1)$ & $(7439-95-4)$ \\
\hline $\begin{array}{ll}\text { Manganese } & (7439-96-5) \\
\end{array}$ & $(7439-9-6)$ & $(7440-02-0)$ & $(7440-09-7)$ \\
\hline$(7782-49-2)$ & $(7740-21-3)$ & $(7440-22-4)$ & $(7440-23-5)$ \\
\hline$(7440-61-1)$ & $(7440-62-2)$ & $(7440-66-6)$ & $(24959-67-9)$ \\
\hline$(16887 \sim 00-6)$ & $(16984-48-8)$ & $(14797-55-8)$ & $(14797-65-0)$ \\
\hline $\begin{array}{ll}\text { Sulfate } & (14808-79-8) \\
\end{array}$ & Phosphate $\quad(14265-44-2)$ & Ammonia $\quad(7664-41-7)$ & $(57-12-5)$ \\
\hline $\begin{array}{l}\text { Total dissolved solids } \\
\text { (TDS) }\end{array}$ & Total suspended solids (TSS) & Total organic carbon $\quad$ (TOC) & $\begin{array}{l}\text { Specific conductivity } \\
\text { (CONDUCT) }\end{array}$ \\
\hline$(\mathrm{PH})$ & & & \\
\hline \multicolumn{4}{|c|}{ Radionuclides } \\
\hline$(12587-46-1)$ & $(12587-47-2)$ & Americium-241 & Antimony-125 \\
\hline (CE/PR-144) & $(13967-70-9)$ & $(10045-97-3)$ & $(10198-40-0)$ \\
\hline$(15510-73-3)$ & Curium-244 (13981-15-2) & Europium-152 & Europium-154 \\
\hline $\begin{array}{ll}\text { Europium-155 } & (14391-16-3) \\
\end{array}$ & Neptunium-237 (13994-20-2) & $(14681-63-1)$ & Plutonium-238 \\
\hline $\begin{array}{l}\text { Plutonium-239/240 } \\
\qquad \text { (PU-239/240) }\end{array}$ & Radium-226 $\quad(13982-63-3)$ & Ruthenium-103 & Ruthenium-106 \\
\hline$(10098-97-2)$ & $(13966-06-8)$ & $(13982-39-3)$ & $(14762-75-5)$ \\
\hline$(15046-84-1)$ & Technicium-99 & $(10028-17-8)$ & \\
\hline
\end{tabular}

(Chemicals Abstract Service number (CAS\#)) 
HNF-3172, Rev. 0

TABLE C-2: General Limits for Liquid Effluent Retention Facility Liner Compatibility.

\begin{tabular}{||l|l|c||}
\hline \multicolumn{1}{|c|}{ Chemical family } & \multicolumn{1}{|c|}{ Constituent(s) or parameter(s) } & $\begin{array}{c}\text { Limit (mg/L) } \\
\text { (sum of constituent } \\
\text { concentrations) }\end{array}$ \\
\hline \hline Alcohol/glycol & benzyl alcohol, 1-butanol (1-butyl alcohol, n-butanol) & 500,000 \\
\hline Alkanone & $\begin{array}{l}\text { acetone, 2-hexanone, methyl ethyl ketone (2- } \\
\text { butanone), } \\
\text { methyl isobutyl ketone (4-methyl-2-pentanone), and } \\
\text { 2-pentanone }\end{array}$ & 200,000 \\
\hline Alkenone & none targeted & 2,000 \\
\hline $\begin{array}{l}\text { Aromatic/cyclic } \\
\text { hydrocarbon }\end{array}$ & $\begin{array}{l}\text { acetophenone, benzene, chlorobenzene, cresol (total } \\
\text { methyl phenol), 1,4-dichlorobenzene, } \\
\text { 2,4-dinitrotoluene, di-n-octyl phthalate, naphthalene, } \\
\text { tetrahydrofuran, toluene, xylene }\end{array}$ & 2,000 \\
\hline $\begin{array}{l}\text { Halogenated } \\
\text { hydrocarbon }\end{array}$ & $\begin{array}{l}\text { carbon tetrachloride, chloroform, 1,2-dichloroethane, } \\
1,2 \text {-dichloroethene, 1,1-dichloroethylene, methylene } \\
\text { chloride, tetrachloroethylene, 1,1,1-trichloroethane, } \\
1,1,2 \text {-trichloroethane, trichloroethylene } \\
\text { (trichloroethene), vinyl chloride }\end{array}$ & 2,000 \\
\hline hexachloroethane & 2,000 \\
\hline Aliphatic hydrocarbon & 2-butoxyethanol & 2,000 \\
\hline Ether & $\begin{array}{l}\text { dimethylnitrosoamine (N-nitrosodimethylamine), } \\
\text { tributyl phosphate }\end{array}$ & 1,000 \\
\hline Other hydrocarbons & none targeted & 100,000 \\
\hline Oxidizers & ammonium & $0.5<\mathrm{pH}<13.0$ \\
\hline Acids, bases, salts & pH & \\
\hline PH & & 500,000 \\
\hline
\end{tabular}

$\mathrm{mg} / \mathrm{L}=$ milligrams per liter 
HNF-3172, Rev. 0

TABLE C-3: Liquid Effluent Retention Facility Maximum Bounding Radiological Source Term.

\begin{tabular}{||l|c||}
\hline \multicolumn{1}{|c|}{ Radionuclide } & $\begin{array}{c}\text { Maximum Bounding Concentration } \\
\text { (curies per liter) }\end{array}$ \\
\hline \hline Tritium & 2.4 E-04 \\
\hline Carbon-14 & $1.6 \mathrm{E}-06$ \\
\hline Cobalt-60 & 2.4 E-06 \\
\hline Selenium-79 & $1.5 \mathrm{E}-07$ \\
\hline Strontium-90 & $4.2 \mathrm{E}-05$ \\
\hline Niobium-94 & $2.6 \mathrm{E}-07$ \\
\hline Technetium-99 & $1.8 \mathrm{E}-05$ \\
\hline Ruthenium-106 & $6.5 \mathrm{E}-07$ \\
\hline Iodine-129 & $1.8 \mathrm{E}-06$ \\
\hline Cesium-134 & $4.1 \mathrm{E}-07$ \\
\hline Cesium-137 & $9.9 \mathrm{E}-06$ \\
\hline Cerium-144 & $8.3 \mathrm{E}-07$ \\
\hline Europium-154 & $9.8 \mathrm{E}-06$ \\
\hline Europium-155 & $6.3 \mathrm{E}-05$ \\
\hline Radium-226 & $6.4 \mathrm{E}-08$ \\
\hline Uranium (gross) & $2.1 \mathrm{E}-10$ \\
\hline Neptunium-237 & $2.1 \mathrm{E}-09$ \\
\hline Plutonium-238 & $2.8 \mathrm{E}-09$ \\
\hline Plutonium-239/240 & $1.7 \mathrm{E}-08$ \\
\hline Plutonium-241 & $2.6 \mathrm{E}-08$ \\
\hline Americium-241 & $1.4 \mathrm{E}-09$ \\
\hline Curium-244 & $2.5 \mathrm{E}-08$ \\
\hline
\end{tabular}


HNF-3172, Rev. 0

This page intentionally left blank. 
HNF-3172, Rev. 0

APPENDIX D

200 AREA TREATED EFFLUENT DISPOSAL FACILITY 
HNF-3172, Rev. 0

This page intentionally left blank. 
HNF-3172, Rev. 0

TABLE D-1: Target Limits for the 200 Area Treated Effluent Disposal Facility.

\begin{tabular}{||l|c|r||}
\hline \multicolumn{1}{|c|}{ Constituent } & Units & Target limit \\
\hline Chloride & $\mathrm{ug} / \mathrm{L}$ & 59,000 \\
\hline Cyanide & $\mathrm{ug} / \mathrm{L}$ & 50 \\
\hline Nitrate & $\mathrm{ug} / \mathrm{L}$ & 620 \\
\hline Arsenic & $\mathrm{ug} / \mathrm{L}$ & 15 \\
\hline Cadmium & $\mathrm{ug} / \mathrm{L}$ & 5 \\
\hline Chromium & $\mathrm{ug} / \mathrm{L}$ & 20 \\
\hline Iron & $\mathrm{ug} / \mathrm{L}$ & 258 \\
\hline Lead & $\mathrm{ug} / \mathrm{L}$ & 10 \\
\hline Manganese & $\mathrm{ug} / \mathrm{L}$ & 50 \\
\hline Mercury & $\mathrm{ug} / \mathrm{L}$ & 2 \\
\hline Total dissolved solids & $\mathrm{ug} / \mathrm{L}$ & 250,000 \\
\hline PH & - & $6.5-8.5$ \\
\hline Bis(2-ethylhexyl) phthalate & $\mathrm{ug} / \mathrm{L}$ & 10 \\
\hline Phenol & $\mathrm{ug} / \mathrm{L}$ & 10 \\
\hline Carbon tetrachloride & $\mathrm{ug} / \mathrm{L}$ & 5 \\
\hline Methylene chloride & $\mathrm{ug} / \mathrm{L}$ & 5 \\
\hline $1,1,1-$ Trichloroethane & $\mathrm{ug} / \mathrm{L}$ & 5 \\
\hline Trihalomethanes (total) & $\mathrm{ug} / \mathrm{L}$ & 66 \\
\hline Radionuclides & - & $<0.04$ of the DCG \\
\hline Gross alpha & $\mathrm{pCi} / \mathrm{L}$ & 15 \\
\hline Gross beta & $\mathrm{pCi} / \mathrm{L}$ & 50 \\
\hline Strontium-90 & $\mathrm{pCi} / \mathrm{L}$ & 8 \\
\hline
\end{tabular}

ug $/ \mathrm{L}=$ micrograms per liter.

$\mathrm{pCi} / \mathrm{L}=$ picocuries per liter.

$\mathrm{DCG}=$ derived concentration guidelines. 
HNF-3172, Rev. 0

This page intentionally left blank. 